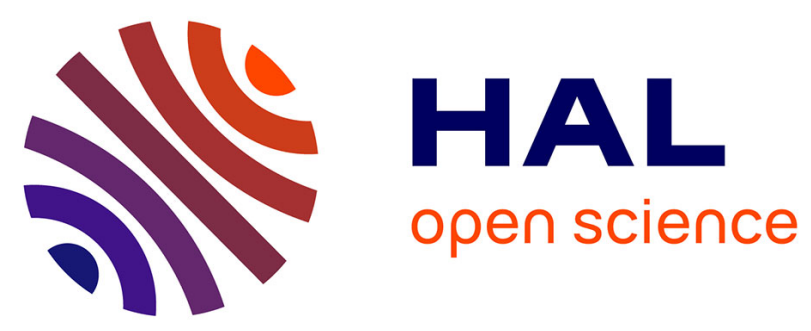

\title{
Study of the Effect of Siliceous Species in the Formation of a Geopolymer Binder: Understanding the Reaction Mechanisms among the Binder, Wood, and Earth Brick.
} Fabrice Gouny, Fazia Fouchal, Pascal Maillard, S. Rossignol

\section{- To cite this version:}

Fabrice Gouny, Fazia Fouchal, Pascal Maillard, S. Rossignol. Study of the Effect of Siliceous Species in the Formation of a Geopolymer Binder: Understanding the Reaction Mechanisms among the Binder, Wood, and Earth Brick.. Industrial and engineering chemistry research, 2014, 53 (9), pp.3559-3569. 10.1021/ie403670c . hal-01016480

\author{
HAL Id: hal-01016480 \\ https://hal.science/hal-01016480
}

Submitted on 11 Jul 2014

HAL is a multi-disciplinary open access archive for the deposit and dissemination of scientific research documents, whether they are published or not. The documents may come from teaching and research institutions in France or abroad, or from public or private research centers.
L'archive ouverte pluridisciplinaire HAL, est destinée au dépôt et à la diffusion de documents scientifiques de niveau recherche, publiés ou non, émanant des établissements d'enseignement et de recherche français ou étrangers, des laboratoires publics ou privés. 


\title{
Study of the $\mathrm{E}$ ect of Siliceous Species in the Form ation of a Geopolym er Binder: Understanding the Reaction M echanism S am ong the Binder, $\mathrm{W}$ ood, and Earth Brick
}

\author{
Fabrice G ouny, ${ }^{\dagger}$ Fazia Fouchal, Pascalm ailard, and Sylie Rossignol* ${ }^{\dagger}$ \\ ${ }^{\dagger}$ G roupe d'Etude desM ateriauxH eterogenes (G EM M M GD ) ,Ecole N ationale Superieure de Ceram ique Industrielle, 12 me A tlantis, \\ 87068 Lim oges, France \\ ${ }^{\ddagger} \mathrm{G}$ roupe dEtude des M ateríux H eterogenes (G EM H G CD ) , Boulevard Jacques D erche, 19300 Egletons, France \\ ${ }^{s_{R}}$ Research and D evelopm ent D epartm ent, Centre T echnique de M ateriaux N aturels de Construction (C TM N C), Ester T echnopole \\ BP 26929, 87069 Lim oges Cedex, France
}

* Supporting Inform ation

ABSTRACT : In building construction, geopolym erbinder orm ortar can interact $w$ th the structuralm aterials and thus $m$ odify the binder form ation m echanism s. In a geopolym er binder, the availability and am ount of siliceous species is a preponderant param eter in uencing the nature of netw ouks form ed after consolidation. In this study, the interactions betw een the binder and structural $\mathrm{m}$ aterials (wood and earth bridks) were investigated by ${ }^{29} \mathrm{Sim}$ agic angle spinning nuclearm agnetic resonance (M AS NM R) and Fourier transform infrared spectroscopy (FT R ) during and after the consolidation. Then, the e ect of the am ount and nature of the siliceous species available in the reaction m edim were analyzed. According to the siliceous species available, it is possible to form di erent types of m aterials (hardening or sedim ented $m$ aterials). By conoborating these results with M AS NM R and FT $\mathbb{R}$ analyses, a form ation schem e of the binder in contact w ith the $m$ aterials was proposed.

\section{$\mathbb{N} T R O D U C T D N$}

Cumently, the reduction of $\mathrm{CO}_{2}$ em issions has becom e a gbbal concem, and the investigation of environm entally friendly $m$ aterials has becom e increasingly im portant. ${ }^{1-3}$ In this context, the use of natural materials, such as the wood and earth $m$ aterials that have been used for severalm illennia, seem $s$ to be relevant. ${ }^{4-6}$ Earth $m$ aterials (ie., un red clay bridks or ram m ed earth) o er many advantages, including a weak em bodied energy, the ability to regulate the relative hum idity of a building as a result of their hygroscopic properties, their abundance in m ost areas, and ease of recycling., Indeed, by using bcal $m$ aterials, the environm ental impact of the construction is drastically reduced as well as the price of the nal product. ${ }^{8}$ $\mathrm{M}$ oreover, A Iinson and $\mathrm{H}$ all have shown that earth walls can bu er relative hum idity changes in a room by adsonbing m oisture in a high hum idity period and releasing it later, which in proves the hygrotherm alcom fort of the building. The wood, from its mechanical characteristics, brings lightness to the structure. Timber frame construction with earth bridk in II appears today as a sustainable design that is prom ising in the building construction ela. However, cracks form at the interfaces of the bridks and frame $w$ ith temperature and humidity uctuations because of shrinkage and swelling phenom ena ( $w$ th wood and earth being hygroscopic). Research on new binders $w$ ith the ability to adhere to wood, especially on earth bridks, has thus been perform ed. . $^{10}$ Am ong the potentialm aterials aumently available, the geopolym er type is a potentially good candidate. For exam ple, a recent study showed that the addition of silica fum e to a geopolym erm ixture leads to the form ation of a form thathas the ability to adhere to wood.11 M oreover, previous works on construction designs made from wood, earth bridks, and these geom aterial foam $s$ have indicated the vibility of these structures by dem onstrating the ability of the geopolym er binder to produce strong bonds between the wood and earth.12,13 $\mathrm{M}$ echanical shear tests on these $m$ asonry have shown that their shear strength values range from 15 to $2 \mathrm{M} \mathrm{Pa}$, depending on the type of bridk. . $^{12}$ Furtherm ore, from the results and observations of pullout tests, the adhesion mechanism was principally explained by mechanical interlocking. ${ }^{13}$ In the case of binder-brick adhesion, it has been shown that there is rst absorption of the binder by the pore of the bridk and then chem ical interactions $w$ ith the creation of an interphase. ${ }^{13}$ In the case of binder-wood adhesion, anchor points were also created by the penetration of the binder inside the pore of the wood before the binder consolidation. This observation was justi ed by an $\mathrm{X}$-ray $\mathrm{m}$ ap of the elem ent potassim realized on the wood/ binder interphase. $12 \mathrm{~N}$ ext, the e ect of the penetration of the binder inside the $m$ aterials and the consequences on the binder formation must be understood. Speci cally, if the binder penetrates the materials, it induces chem ical interactions that could modify the reaction mechanisms during the consolidation. Investigation of the nature of the netwolks form ed after consolidation and contact $w$ th the $m$ aterials is thus necessary.

G eopolym ers are am orphous three-dim ensional alum inositicate binder $m$ aterials that are synthesized at am bient tem perature by the alkaline activation of alum inositicate sources, such

Received: O ctober 30,2013

Revised: Jenuary 27,2014

Accepted: February 10, 2014

Published: February 10, 2014 
as calcined clays, industrial waste, and more.14,15 These $m$ aterials show good resistance to high tem peratures and acid degradation, as well as good com pressive strength. Their form ation results from the dissolution and reorganization of raw $m$ aterials. First, reactive alum inositicate sources are dissolved to form free $\mathrm{Si}[\mathrm{OH}]_{4}$ and $\mathrm{Al}[\mathrm{OH}]_{3}$ species, which will then react by a polycondensation reaction to form an am orphous geopolym er network. To further understand and highlight the di erent netwolk form ations, atom ic bond scale analyses ( $\mathrm{Si} \mathrm{O}-\mathrm{M}, \mathrm{M}=\mathrm{Si}, \mathrm{K}, \mathrm{Al}$ ) are necessary. $\mathrm{M}$ agic angle spinning nuclearm agnetic resonance (M AS N M R) analysis is a useful characterization technique for investigating the silicon environm ent in the binder. This technique allows the determ ination of the di erent netwolks that can be form ed in the binder after contact and consolidation with the natural m aterials. ${ }^{29}$ SiM AS N M R analysis, conducted by Autefetal on geopolym er m aterials, has highlighted di erent contrbutions that comespond to di erent silicon environm ents. ${ }^{16}$ These results showed ve contributions centered around $-80,-88$, $-97,-106$, and -113 ppm, which are attributed to $\left.Q^{3}(2 A]\right)$, $\mathrm{Q}^{4}(3 \mathrm{~A} I), \mathrm{Q}^{4}(2 \mathrm{~A} 工), \mathrm{Q}^{4}(1 \mathrm{~A} I)$, and $\mathrm{Q}^{4}(\mathrm{OA} I)$ from silicic acid bonds, respectively (m ore details in the Results). In situ Fourier transform infrared spectroscopy (FT R ) is anotherw idely used technique for the study of the formation of the polymer netw ork. ${ }^{17}$ It is partiaularly e cient for follow ing the structural evolution of $m$ aterials in the polfm exization process, notably, the substitution of $\mathrm{Si-O-Si} \mathrm{by} \mathrm{Si-O-Al} \mathrm{bonds,} \mathrm{which} \mathrm{is}$ characteristic of the geopolym erization reaction. ${ }^{18}$

This work thus com pletes previous works on the use of a geopolym er binder in tim ber-firm ed constuction using earth bridks as in II. This study attem pts to understand the reaction m echanism s intervening between the natural geopolym eric binder and natural materials (wood and earth bridk) and proposes a form ation m odel of the binder in the function of $\mathrm{m}$ aterials in contact. First, the results of in situ FT $\mathbb{R}$ and ${ }^{29} \mathrm{Si}$ M AS NM R analyses penform ed on the binder, which was consolidated in contact $w$ ith $m$ aterials, are presented. N ext, 30 geopolym er binder form ulations were investigated by in situ ATR (attenuated total re ection) FT R analysis, which should allow a better understanding of the e ect of the siliceous species on the nature of the form ed netwolks.

\section{ATERIALS AND M ETHODS}

Raw M aterials. In this study, several preaursors and raw $m$ aterials were used $w$ ith distinguiched precursors for the binder synthesis and raw $m$ aterials used for the building system (earth bridk and wood). Conceming the m ineral polym er binder, various samples were synthesized using potassium hydroxide pellets ( $85.7 \%$ purity), potassim silicate solution $\left(\mathrm{H}_{2} \mathrm{O}=76.07 \%, \mathrm{Si} \mathrm{O}_{2}=16.37 \%\right.$, and $\mathrm{K}_{2} \mathrm{O}=756 \%$ ), m etakaolin M 1000 from AGS (C lerac, France), and silica fum e. Three types of silica were used: silica fum e supplied by Feropem (denoted FD S) , silica fum e supplied by C abot (denoted M 5), and crushed quartz (denoted Si400).D etails of all silica used in this work are presented as Supporting Inform ation (T able S1) .

Conceming m aterials applied for the building system, two extrusion m anufactured industrial earth bridks were chosen, the sam e bridks used in previous work..$^{12,13}$ The bridks di ered in $\mathrm{m}$ ineral com position (denoted $\mathrm{B} r_{1}$ and $\mathrm{Br}_{2}$ ), and their densities were 1.70 and $2.00 \mathrm{~g} \mathrm{~cm}^{3}$ for $\mathrm{Br}_{1}$ and $\mathrm{Br}_{2}$, respectively. A bcal com pany of Lim oges, France, supplied D ouglas r wood that was dried and planed. The details of assem bly m anufacturing are presented in previous wolk.12,13
Sam ple Preparation. All binders were prepared by magnetic stining of the potassim hydroxide pellets in the solution of potassim silicate, followed by the addition of the silica fume (or quartz) and metakaolin. It is important to distinguish that the reference FD $S_{100}$ binder is used for the nal composite system and the other binders were used to investigate the e ect of silica on the nature of the networks form ed during the consolidation of the material Figure 1 sum $m$ arizes the synthesis protocol of foam FD $S_{100}$ and other binders.

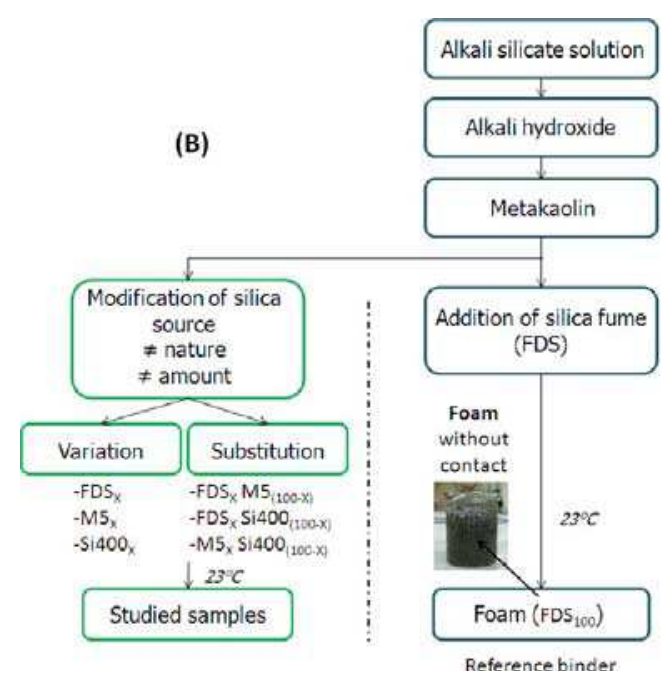

Figure 1. Synthesis protocol of geom aterial foam (A) and other sam ples synthesized based on foam form ulation (B).

The type and am ount of silica introduced into the $m$ ixture directly in uence the characteristics of the nal binder. To assess their in uence, two binder series have been developed, which are noted as substitution (FD S $S_{X} M 5_{100 x} ; F^{F} S_{X} S$ i $400_{100 x}$;

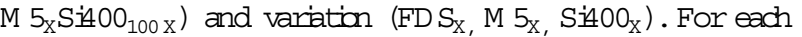
series of binder, the am ount of m etakaolin, potassim silicate, and potassim hydroxide rem ain identical, as for the reference foam FD $S_{100}$; only the type and the am ount of silica added to the $m$ ixture have been m odi ed. $N$ om enclature exam ples for the synthesized binders are presented as Supporting Inform ation ( $T$ able S2). The indexed num ber between 0 and 100, which appears after the name of the used sitica, is the weight percent of the silica introduced into the $m$ ixture. The substitution sam ples have the sam e weight percent of silica as the reference FD $\mathrm{S}_{100}$; only the type of each silica introduced changes. For variation samples, the weight percent of introduced silica varies from 0 to $100 \%$ in $20 \%$ increm ents. Shown on Si-A - K-O temary, it is noted that synthesized binders comespond to sedim entary $m$ aterials and gels according to the wolk of $\mathrm{G}$ ao et al, ${ }_{1}^{19}$ as shown in Figure 2 .

To evalluate the e ect of the contact of the structural $m$ aterials (earth bridks and wood) on the consolidation and netw olk form ation of the reference binder FD $S_{100}$, the binder in contact with these materials was analyzed. For this experm ent, a hole was drilled in the materials, and the reference binder (foam FD $S_{100}$ ) was poured inside. In situ FT $\mathbb{R}$ analysis was perform ed during consolidation and M AS NM R anakysis after consolidation.

Characterization Techniques. FT $\mathbb{R}$ spectra were obtained using a Thermo Scienti c Nicolet 380 infrared 


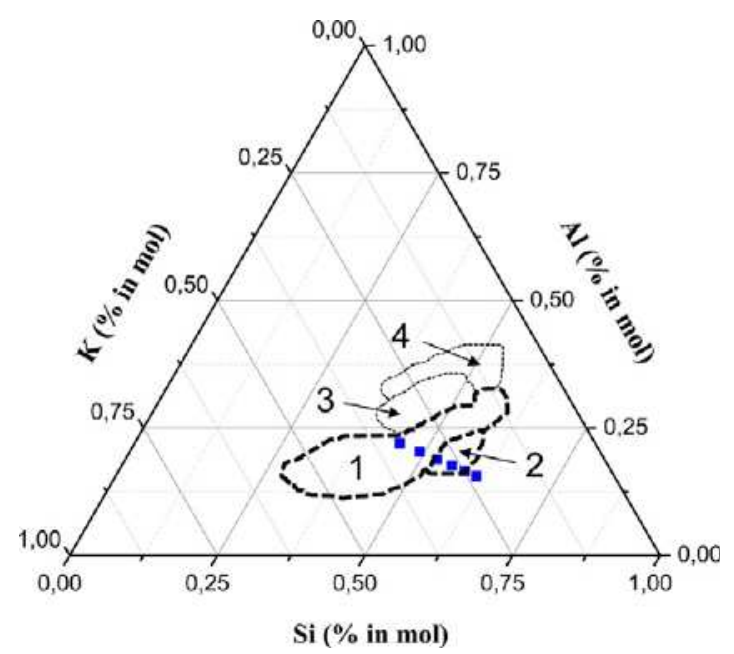

Figure 2. Blue squares show the position of $m$ ixtures synthesized on the (Si- Al $\mathrm{K}-\mathrm{O}$ ) temary (existence dom ains of several $\mathrm{m}$ ixtures proposed by $\mathrm{G}$ ao et al: 1 , sedm ented m aterials; 2 , gel; 3, geopolym er; and 4 , hardening $m$ aterials). spectrom eter using the ATR m ethod. The $\mathbb{R}$ spectra were collected between 500 and $4000 \mathrm{~cm}^{-1}$, with a resolution of 4 $\mathrm{cm}^{-1}$. To m onitor sam ple form ation, a m acro was used that allowed spectra to be recorded every $10 \mathrm{~m}$ in for $10 \mathrm{~h}$. The acquisition was initiated affer placing a drop of sam ple, or the $m$ aterial w ith binder inside, onto a dim ond substrate. Finally, overlaid raw spectra were obtained. To rem ove the contribution from atm ospheric $\mathrm{CO}_{2}$, the spectra were conrected $\mathrm{w}$ ith $\mathrm{a}$ straight line between 2280 and $2400 \mathrm{~cm}^{-1}$. The spectra were comected using a baseline and then norm alized before being com pared.

$\mathrm{H}$ igh-resolution M AS N M R experm ents were penform ed at room tem perature in a Bruker AVANCE-400 spectrom eter operated at $79.49 \mathrm{M} \mathrm{H} \mathrm{z}\left({ }^{29} \mathrm{Si}\right.$ signal). The ${ }^{29} \mathrm{Si}(\mathrm{I}=1 / 2) \mathrm{M} \mathrm{AS}$ NM R spectra were recorded after $\square / 2$-pulse inadiation (4 ls) using a $500 \mathrm{kH} \mathrm{z}$ lter to in prove the signal/noise ratio. In the M AS NM R experm ents, powder som pleswere spun at $10 \mathrm{kH} z$. The num ber of scans was 400 for silicon. The tim e between accum ulations was set at $10 \mathrm{~s}$ to $\mathrm{m}$ inm ize saturation e ects. Spectral deconvolution was perform ed using the $\mathrm{W}$ in $t$ (Bruker) software padkage. The deconvoluted spectra are only used qualitatively, and no quantilative studies have been perform ed.
(A)

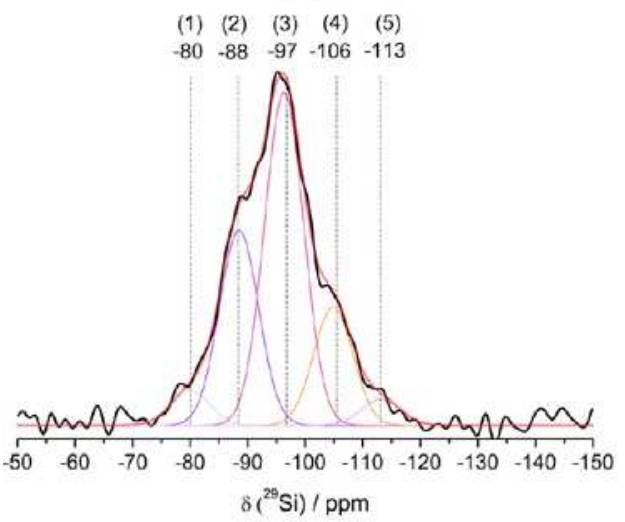

(B)

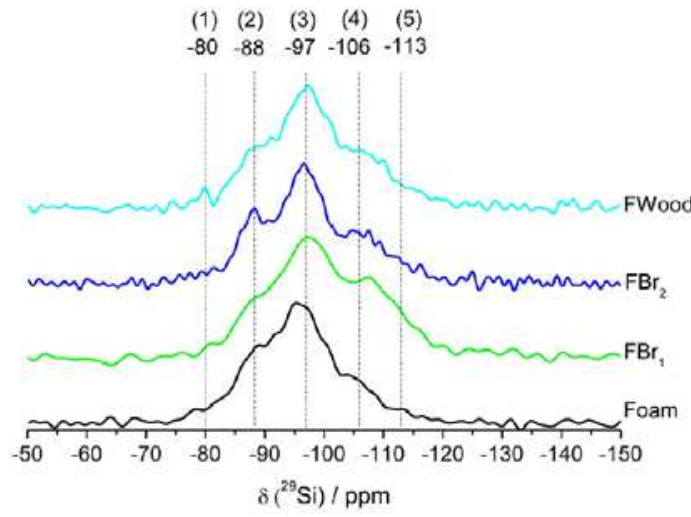

(C)

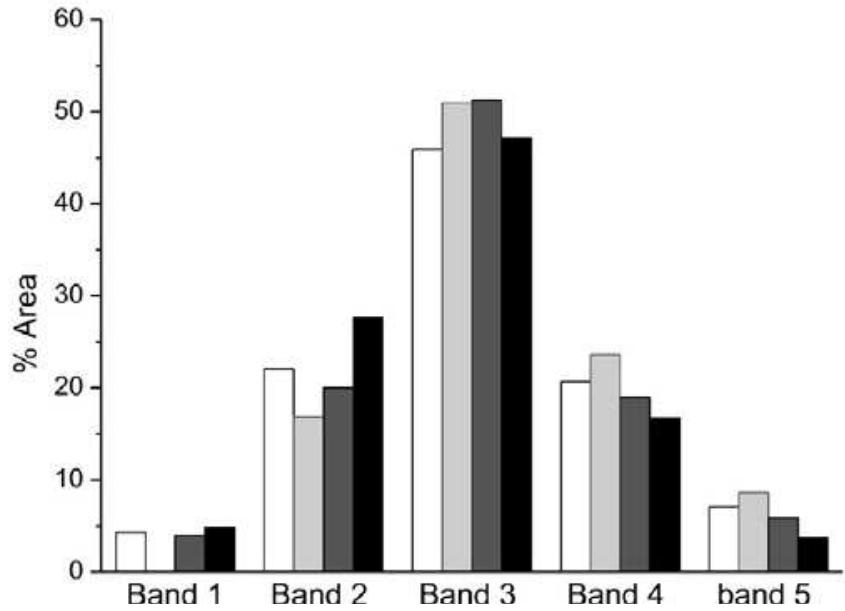

Figure $3 .{ }^{29}$ SiM AS NM R results: (A) deconvoluted spectra in the case of FD $S_{100}$ (foam); (B) exprerm ental data for FD $S_{100} W \infty 0 d, F D S_{100} B r_{1}$, FD $S_{100} \mathrm{Br}_{2}$, and FD $S_{100}$; and (C) percentage of the area ofeach contribution determ nided from deconvulated spectra for (white) FD $\mathrm{S}_{100} \mathrm{~W}$ ood, (light gray) FD $\mathrm{S}_{100} \mathrm{Br} r_{1}$, (dark gray) FD $\mathrm{S}_{100} \mathrm{Br}_{2}$, and (bladk) FD $\mathrm{S}_{100}$. 
W ettability tests were perform ed by placing a drop of foam FD $S_{100}$ on the wood and bridks at room tem perature. Contact angle, absorption, and spreading characteristics were observed.

The BET speci $c$ surface area of the silicas was determ ined by $\mathrm{N}_{2}$ adsorption at $-19585^{\circ} \mathrm{C}$ using a M icrom etrics Tristar II 3020 volum etric adsorption/desorption apparatus. Prior to m easurem ent, the samples were degassed at $200{ }^{\circ} \mathrm{C}$ under vacurm for $4 \mathrm{~h}$ (Supporting Inform ation, Table S1) .

\section{RESULTS}

Interaction between M aterials. To determ ine if the adhesion between the materials is possible, it is im portant to obtain data on the wetting properties and $m$ aterials sunface.

W ettability Test. W ettability test results are gathered as Supporting Inform ation (Table S3).W ettability tests on bridks and wood provide inform ation about the drop spreading and underine the di erent absorption properties of the materials. The wettability tests show that the contact angle at $t=0$ was closed to $90^{\circ}$ forwood and $\mathrm{B} r_{1}$, while for $\mathrm{B} r_{2}$ it is bebw $90^{\circ}$. At $t=7 \mathrm{~m}$ in allangles are below $90^{\circ}$. This result therefore justi es an adhesive compatibility between these materials. The absorption is signi cantly higher for bridk $\mathrm{Br}_{1}$ than for bridk $\mathrm{Br}_{2}$. After less than $5 \mathrm{~m}$ in, an aureole was visible around the drop deposited on $\mathrm{B} r_{1}$, justifying the absorption of part of the binder by the bridk. For $\mathrm{Br}_{2}$, no aureole was observed, which can be explained by a di erence in term s of total porosity and pore size distribution of the bridks. The porosity values determ ined by merary intrusion of each bridk are 35\% and $21 \%$ for $\mathrm{Br}_{1}$ and $\mathrm{Br}_{2}$, respectively. ${ }^{12} \mathrm{M}$ oreover, the $\mathrm{m}$ edian pore dim eter of the $\mathrm{Br}_{1}$ bridk is approxim ately $3.7 \square \mathrm{m}$, and the pores are m ostly between 1 and $10 \llbracket \mathrm{m}$. For the $\mathrm{Br}_{2}$ bridk, the pores are $s m$ aller, $w$ ith a pore size distrbution ranging from 0.005 to 08 m and the m edian diam eter at approxm ately 0.7 $\mathrm{m}$. Penetration of the binder into the bridk depends on the pore size. In the case of the $\mathrm{Br}_{1}$ bridk, the binder can easily penetrate into the large pores, allowing it to penetrate deeper and faster com pared to the $\mathrm{Br}_{2}$ bridk. For wood, absorption is interm ediate and di ers according to its nature, as it is more im portant for the spring wood than the sum m erwood. ${ }^{20}$ These observations w anrant a penetration ofbinderm aterials. The bw contact angle also re ects an easy adhesion between these m aterials.

The wettability tests have shown that there was binder penetration through the pores of the $m$ aterial This observation is conoborated by the mechanical shear and pullout tests perform ed in a previous study. ${ }^{13}$ The penetration of the binder induces necessary chem ical interactions, w th $\mathrm{m}$ aterials being able to modify the nature of the networks form ed inside the once consolidated binder.

Analysis of Interactions between the Binder and Structural M aterials. To highlight and better understand the various interactions occuming at the bcal scale, nuclear m agnetic resonance and FT $\mathbb{R}$ spectroscopic analyses were perform ed to determ ine the environm ents of the siticated species of the binder.

M A.S NM R Analysis. The silicated species are descrbed $w$ ith the usual notation, $\mathrm{Q}^{\mathrm{n}}$, where $\mathrm{n}$ ranging between 0 and 4 indicates the degree of connectivity of silicon, ie., the num ber of bridging oxygens. ${ }^{21}$ The di erentiation of the num erous species is obtained by the study of the chem ical shifl, which strongly depends on the coordination num ber of silicon. In a geopolym eric binder, the siticon is principalty in a tetrahedral coordination and is bonded with alum inum. Thus, for geopolym erm aterials, the $\mathrm{Q}^{\mathrm{n}}$ (mAl) notation is used to describe the environm ent of siticon, where $m$ ranges from 0 to 4 and represents the number of connected alum inum atom s. As before, $n$ ranging between 0 and 4 indicates the number of bridging oxygens. ${ }^{22}$ For example, Autef et al have put in evidence for a dense geopolym er for which bands centered around $-90,-95,-100,-105$, and -110 ppm can be attributed to $Q^{4}(4 \mathrm{~A} I), \mathrm{Q}^{4}(3 \mathrm{~A} I), \mathrm{Q}^{4}(2 \mathrm{~A} I), \mathrm{Q}^{4}(\mathrm{IA} I)$, and $\mathrm{Q}^{4}(\mathrm{OA} I)$, respectively. ${ }^{23} \mathrm{M}$ oreover, it has to be noted that in function of the chem ical com position the position of the band can be sightly di erent. ${ }^{24}$

Figure 3A shows the spectrum of the reference binder (foam $F D S_{100}$ ) used for the construction of the building system. This spectrum was deconvoluted into ve contributions, in accordance with the phases highlighted by the work of Prudhom m e et $\mathrm{l}^{25}$ on thism aterial: three m ajor contributions centered at $-88,-97$, and -106 ppm , denoted as contribution 2,3 , and 4, respectively, and two m inor contributions centered at -80 and -113 ppm, denoted as contribution 1 and 5, respectively.

$M$ inority phases $m$ ay be attributed to the contribution of depolym erized species [species $\left.Q^{3}(1 \mathrm{~A}]\right)$, Tognonviet $\mathrm{Il}^{26}$ ] for band 1 ( -80 ppm ) and silicic acid forband 5 (- 113 ppm ) . 27,28

Band 2 (- 88 ppm ), present in the binder, can be attributed to the main contribution of the geopolym er phase. ${ }^{29}$ In comparison to the literature on geopolym er materials, the position of the observed chem ical shift (band 2) varies sightly. This can be explained by the di erence of the reaction m edium as a result of the release of dihydrogen and di erent levels of silica. ${ }^{13,25}$ Contribution 4, centered around - 106 ppm, can be attributed to quart $z^{30,31}$ present in the metakaolin or silicate species of silica gel ${ }^{26,16}$ Finally, contribution 3, the largest band bcated at - 97 ppm , m ay be attributed to (i) a zeolite phase, (ii) $\mathrm{a} \mathrm{K}_{2} \mathrm{Si}_{2} \mathrm{O}_{5}$ phase, or (iii) the presence of siliceous species in $\mathrm{Q}^{3}(2 \mathrm{Al})$ comresponding to an environm entofan alum inosilicate $m$ aterial ${ }^{25,32-36}$ This contribution $w$ ill be used for reference later in the study as the prim ary allm inosilicate com pound, but it should be noted that the elem ent potassim is also present.

Figure 3B presents the ${ }^{29} \mathrm{SiM}$ AS NMR spectrum of the reference binder (foam $\mathrm{FD} \mathrm{S} \mathrm{S}_{100}, \mathrm{Si} / \mathrm{K}=2.6, \mathrm{Si} / \mathrm{Al}=3.93$ ) and the spectrum of the sam e binder consolidated in contact $w$ ith each of the three materials ( $F D S_{100} \mathrm{Br}_{1}, \mathrm{FDS}_{100} \mathrm{Br}_{2}$, and FD $S_{100}$ W ood).

In general, whichever $m$ aterial is in contact $w$ th the binder, there is always a prevalence of band 3 centered at - 97 ppm (Figure 3B). O ther contributions bcated at $-88,-106$, and - 113 ppm show variable intensities. It should be noted that contribution 1 ( -80 ppm ) is not detected on the deconvoluted spectrum of the FD $\mathrm{S}_{100} \mathrm{Br} \mathrm{r}_{1}$ som ple.

To understand the phenom ena responsible for these intensity di erences, the integrated area of each contribution for $\mathrm{FD} \mathrm{S}_{100} \mathrm{~W}$ ood, FD $\mathrm{S}_{100} \mathrm{Br}_{1}, \mathrm{FD} \mathrm{S}_{100} \mathrm{Br}_{2}$, and $\mathrm{FD} \mathrm{S}_{100}$ (form ) sem ples was plotted in $\mathrm{F}$ igure $3 \mathrm{C}$. This representation allows for the evaluation of the contributions of the di erent netw orks present after consolidation. As seen above, contribution 3 is alw ays present and was therefore considered as the $m$ ain band. This shows that the species $w$ ithin the porous alum inosilicate geopolym er binder are not changed. It should be noted that contribution 2, attributed to the geopolym er phase, decreased for all the sam ples. This suggests a decrease of alum inosilicate species inside the binder necessary for the form ation of the geopolym er netwolk. This fact is more pronounced for the FD $S_{100} \mathrm{Br}_{1}$ sm ple. In retum, this phenom enon is com pensated 
forby an increase in the contributions of environm ents 4 and 5 for all the sam ples, but in di erent proportions, depending on the substrate in contact $w$ ith the binder.

(i) In the case of wood support ( $F D S_{100} \mathrm{~W}$ ood), the sight decrease of the geopolym er band ( -88 ppm ) associated w ith an increase of the characteristic band of silica gel (- 106 ppm ) and silicic acid (- $113 \mathrm{ppm}$ ) is a result of the penetration of the binder into the wood bers. Indeed, this very hygroscopic support has a high a nity for alkaline aqueous solutions. ${ }^{37}$ This is in agreem ent $w$ ith the transfer of the potassium elem ent observed in a previous study. ${ }^{12}$ The species in interaction $w$ ith the wood are silicated species enriched with potassim .

(ii) In the case of the $\mathrm{FD}_{100} \mathrm{Br}_{2}$ sam ple, the bw intensity of the contribution of silicic acid ( 113 ppm ) can be explained by an in-depth Iim ited penetration of the binder. Indeed, this bridk composed of $\mathrm{sm}$ all pores (from 0.01 to $080 \square \mathrm{m}$ ) does not allow the species present in the reaction m edium to penetrate deeply $(<100 \square \mathrm{m})$ into the bridk. This factw illbcally induce an alteration of the bridk by a partial dissolution of clays in the alkaline m edium and release species that $\mathrm{w}$ in be able to react and supply the geopolym er phase whose contribution varies sightly.

(iii) In the case of the $\mathrm{FD} \mathrm{S}_{100} \mathrm{Br}_{1}$ sam ple, the binderw ill also enter the bridk but m ore deeply $(>500 \square \mathrm{m})$ as a result of its higher pore size $(1-10 \square \mathrm{m})$. In this case, the species released by the deterioration of bridk will tend to react bcally, consum ing the species necessary for the formation of the geopolym erphase in the binder. This w ill result in the creation of di erent speciation equilibrim s and thus create a chem ical interaction in the liquid prearsor, thus changing the $\mathrm{pH}$ value. Then, there w illbe a reduction in that value which w illprom ote the appearance of sitica gel and silicic acid. ${ }^{39}$

The bw contribution at -80 ppm for FD $S_{100} \mathrm{~W}$ ood and FD $S_{100} \mathrm{Br}_{2}$ characterizes the presence of alum inositicate depolym erized diluted species. ${ }^{40}$ These $m$ aterials w ill not be able to condense and participate in the various netw orks. In the case of the FD $\mathrm{S}_{100} \mathrm{Br}_{1}$ sam ple, with the reaction $\mathrm{m}$ ixture having di used into bridk, there is little or no form ation of these isolated depolym erized species.

The NMR spectroscopy results have evidenced various netwolks form ed affer interactions with $m$ aterials.

In Situ FTR Analysis. FTR spectroscopy results on the binder $w$ ith support tests $\left(F D S_{100} \mathrm{Br}_{1}, \mathrm{FD} \mathrm{S}_{100} \mathrm{Br}_{2}\right.$ and FD $S_{100} \mathrm{~W}$ ood) provide information on possible interactions during the consolidation of the binder in contact with the $m$ aterials. In situ m ontoring of samples over a $10 \mathrm{~h}$ period gives inform ation about the reanrangem ent of the network. In partiaular, the band centered at approxm ately $980 \mathrm{~cm}^{-1}$ shifts to a bwervalue during the form ation, which is characteristic of the geopolym erization reaction and comresponds to the Si O $\mathrm{M}(\mathrm{M}=\mathrm{Si}$ or $\mathrm{Al})$ vibration band.2,18 By monitoring this displacem ent, it is possible to evaluate the kinetics of the geopolym erization (sbpe of the arrve) and the structural evolution of the netwolk (total displacem ent of the band). In situ FT $\mathbb{R}$ m ontoring tests perform ed on the reference binder, FD $S_{100} \mathrm{~W}$ ood, $F D S_{100} \mathrm{Br}_{1}$, and $F D S_{100} \mathrm{Br}_{2}$ show a strong di erence in term $s$ of reaction kinetics and form ed networks. This result con $\mathrm{m}$ s the interactions between the binder and $m$ aterials during the consolidation. Figure 4 shows the evolution of the position of the band comesponding to the Si- O - M bonds versus tim e for F' $S_{100}, F^{\prime} S_{100} \mathrm{Br}_{1}, F D S_{100} \mathrm{Br}_{2}$, and FD $S_{100} \mathrm{~W}$ ood sam ples. The variations $m$ ay be divided into two regim es depending on time. At the beginning, for all

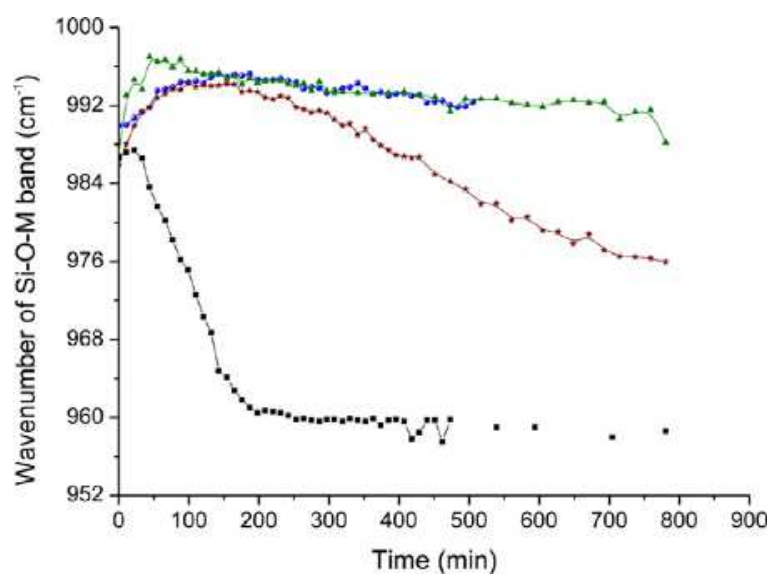

Figure 4.W avenum ber evolution of the Si O - M band as a function of time for (blue circle) FD $\mathrm{F}_{100} \mathrm{Br}_{1}$, (red star) $\mathrm{FD} \mathrm{S}_{100} \mathrm{Br}_{2}$, (green triangle) FD $S_{100} \mathrm{~W}$ ood, and (bladk square) FD $\mathrm{S}_{100}$ (foam ).

sam ples, there is an increase of the displacem ent value of the band Si-O-M . After approxm ately $100 \mathrm{~m}$ in, there is an inversion of variation.

(i) From the rstm inutes of the reaction ( $t<100 \mathrm{~m}$ in), the increase of the position of the Si- O-M band translates to di erent speciation equilibrim s, likely resulting from absorption phenom ena by the various supports. This suggests that there is Si O - Sientities form ation as silicic acid is observed by NM R ${ }^{26}$

(ii) After $100 \mathrm{~m}$ in, two types of behaviors are observed, one characteristic of geopolym erization reactions $w$ th a signi cant decrease in the $\mathrm{Si} \mathrm{O}-\mathrm{M}$ band position $\left(\mathrm{FD} \mathrm{S}_{100} \mathrm{Br}_{2}\right.$ ) and the other characteristic of a m etastable equilibrim $w$ ith very little variation of displacem ent (FD $S_{100} \mathrm{Br}_{1}$ and $F D S_{100} W$ ood). In the case of the $\mathrm{FD} \mathrm{S}_{100} \mathrm{Br}_{2}$ sam ple, the existence of interactions between the altered clay particles and the reaction m edim can lead to various alum inosilicate netw orks observed by N M R . For FD $S_{100} \mathrm{Br}_{1}$ and FD $\mathrm{S}_{100} \mathrm{~W}$ ood sam ples, as a result of greater binderpenetration into the support, the speciation equilibrium s are modi ed. This leads to a metastable state that is characterized by few transfers of species. Interactions are Im ited, and thus, in situ geopolym erization reaction detection is di allt.

These results are in agreem ent $w$ ith the wettability tests presented previously, which show that the absorption tim e of a drop of binder is m ore im portant for $\mathrm{Br}_{1}$ bridk than forwood and the $\mathrm{Br}_{2}$ bridk.

$\mathrm{E}$ ect of Siliceous Species on the Binder Form ulation M echanism. D i erences were observed between the binder abne and the binder in contact. The di erences were explained by a variation of the availability of the siliceous species. It then appears judicious to understand the role of certain siliceous species in speciation equilibrim s by m odifying the am ount of silica introduced. N ew form ulations denoted "variation" and "substitution" were tested, where the nature and the am ount of silica introduced were the param eters of study. In this case, each binder was consolidated under the environm ental conditions w ithout support contact. Six di erent sets of form ulations were synthesized and analyzed by in situ FT $\mathbb{R}$.

Description of Substilution and Variation Tests. For each form ulation of each set, the m onitoring of the Si O - M band was perform ed and the total displacem ent and sbpe of the arve were $m$ easured and com pared. Parts A and B of Figure 5 
(A)

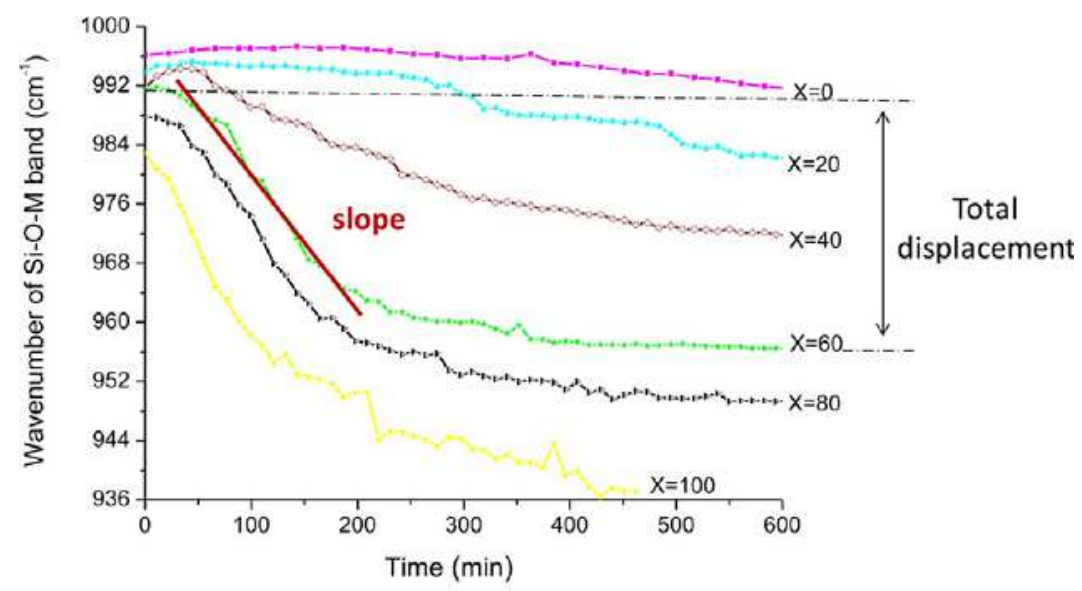

(B)

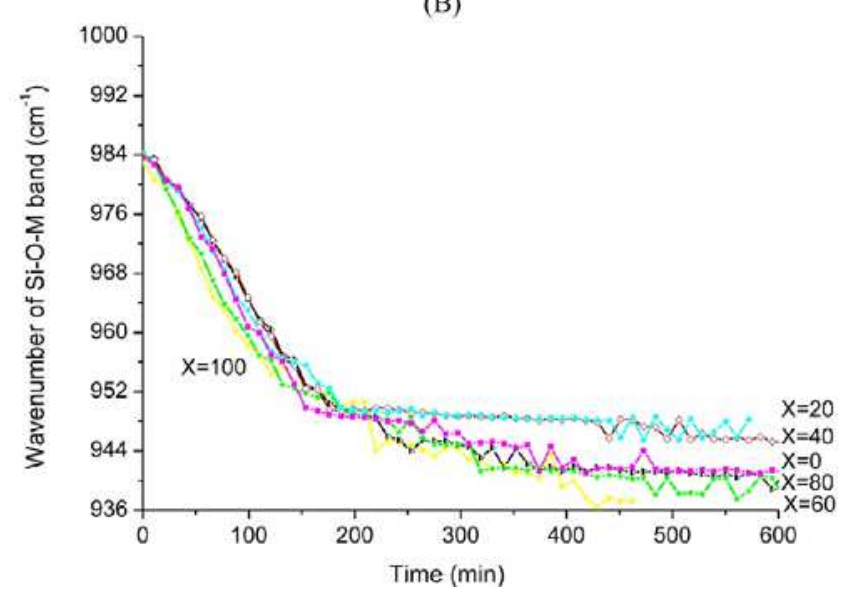

Figure 5. Evolution of Si- O - M band position in function of tim e for (A) SiH00 $\mathrm{M} 5_{100-\mathrm{X}}$ and (B) SiH00 series.

present the evolution of the $\mathrm{Si} \mathrm{O}-\mathrm{M}$ band position as a function of tim e for the series substitution Sin00 $\mathrm{X} 5_{100 \mathrm{x}}$ and variation $\mathrm{SiH}_{\mathrm{H}} \mathrm{O}_{\mathrm{X}}$, respectively.M oreover, a picture of all sam ples synthesized was taken after 1 week of drying at ambient tem perature and are gathered as Supporting Inform ation (Table S4). It is observed that as a function of type and am ount of silica added, the m orphobgy of the smples di er. Subsequently, both the features of the sam ples synthesized as well as the m onitoring of the Si- O - M band w ill be discussed.

$\mathrm{FDS}_{\mathrm{X}} \mathrm{Si} 400_{100 \mathrm{X}}$. The FD $\mathrm{S}_{0} \mathrm{~S}$ i4 $00_{100}, \mathrm{FD} \mathrm{S} \mathrm{S}_{20} \mathrm{SiH}_{40}$, and $\mathrm{FD} \mathrm{S}_{40} \mathrm{~S}$ i400 60 samples show two distinct phases after consolidation: one having the appearance of a dense geopolym er w thout cradking (bwer phase) and the other being glassy, sim ibr to a silica gel (top). The other form ulations ( $\mathrm{FD} \mathrm{S}{ }_{60} \mathrm{SiH}_{40}$ and $\mathrm{FD} \mathrm{S}_{80} \mathrm{SiH} 0 \mathrm{O}_{20}$ ) have a uniform appearance but $w$ ith shrinkage on the bottom and an upper portion resem bling a gel Both types of behavior are prim arily because of the FDS/Si400 ratio that imposes the rate of silicon available, which goes into solution and participates in the reaction. Regardless of the sam ple type, there is a decrease of the displacem ent value, which characterizes the polycondensation reactions between the di erent allm inosilicate species. H ow ever, the m ore sitica Sif00 increases, the m ore the overall value of the displacem ent quidkly increases. This result can be explained by the follow ing param eters. (i) $\mathrm{W}$ hen $\mathrm{X}=0$, a reagent $\mathrm{m}$ ixture between the m etakaolin and the alkaline solution is created, which leads to the geopolym er netwolk form ation. Excess species that do not react contribute to the developm ent of a gel on the surface. Sif00 particles are encapsulated in the geopolym er binder.

(ii) $\mathrm{W}$ hen $0<\mathrm{X}<60$, competition between di erent netwolks (geopolymer and gel) exists by the interaction of silica fum e FDS, which generates dihydrogen and releases siliceous species that can participate in geopolym eric netw orks.

(iii) $W$ hen $X \quad 60$, a very high reactivity of the silica fum $e$ FD $S$ is observed, which controls the reactivity of the m edim by releasing siliceous species.

FD S $S_{X} M 5_{100 x}$. All somples in this series exhibit one phase, except for the biphasic FD $\mathrm{S}_{20} \mathrm{M} 5_{80}$. A di erence of volume expansion is observed in these smples, which is more im portant than the high am ount of FD S silica. ${ }^{41}$ The shifl of the Si O - M band decreases when the proportion ofM 5 silica fum e increases. The di erence in reactivity of the two silicas is directly related to their speci c surface area, 40 and $202 \mathrm{~m}^{2} / \mathrm{g}$ for FD S and M 5, respectively. In the presence of a signi cant am ount of M 5, after several m inutes, the m edim becom es saturated with siliceous species. Then, there is competition between the formation of a Si-rich netwolk and geopolym erization reactions, which are characterized by a very low shift of the Si-O-M band. This observation is 
(A)

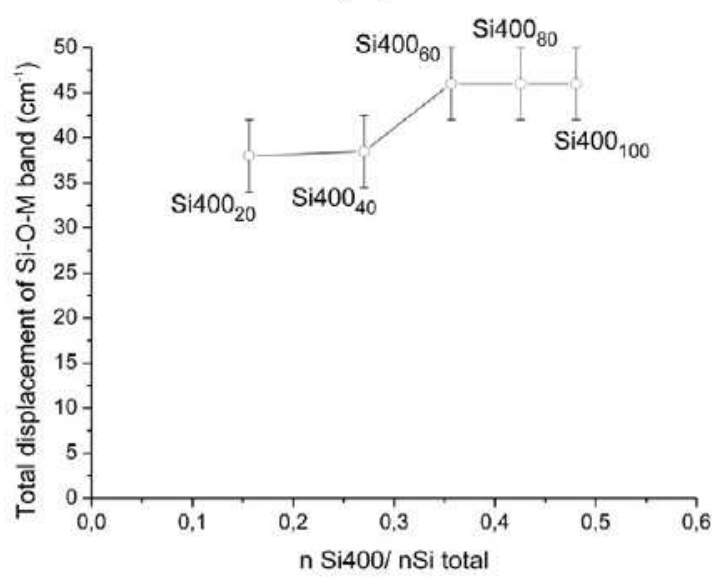

(C)

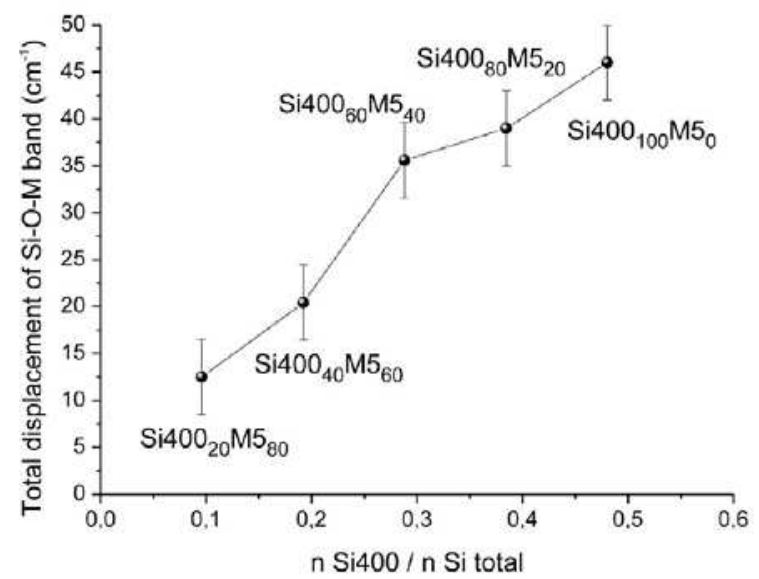

(E)

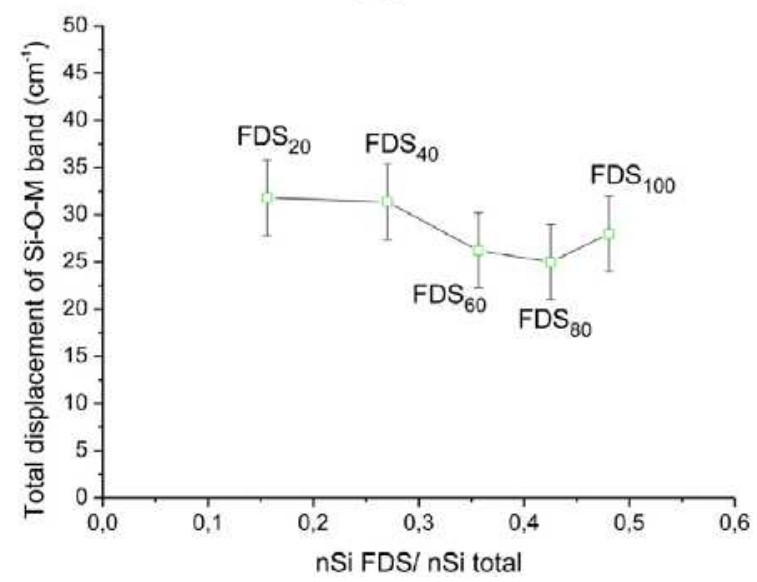

(B)

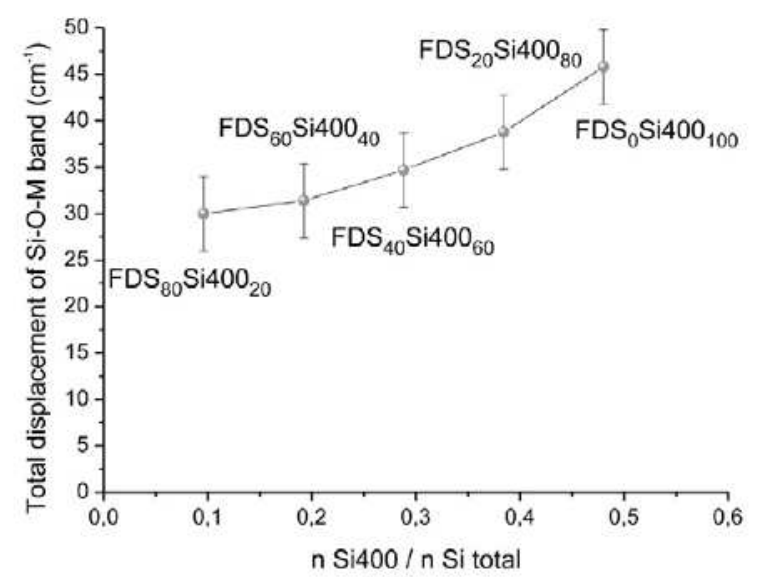

(D)

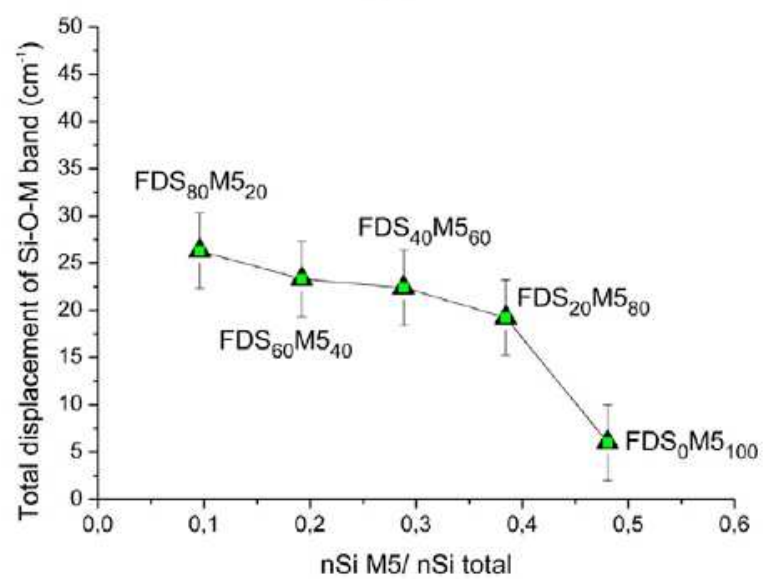

(F)

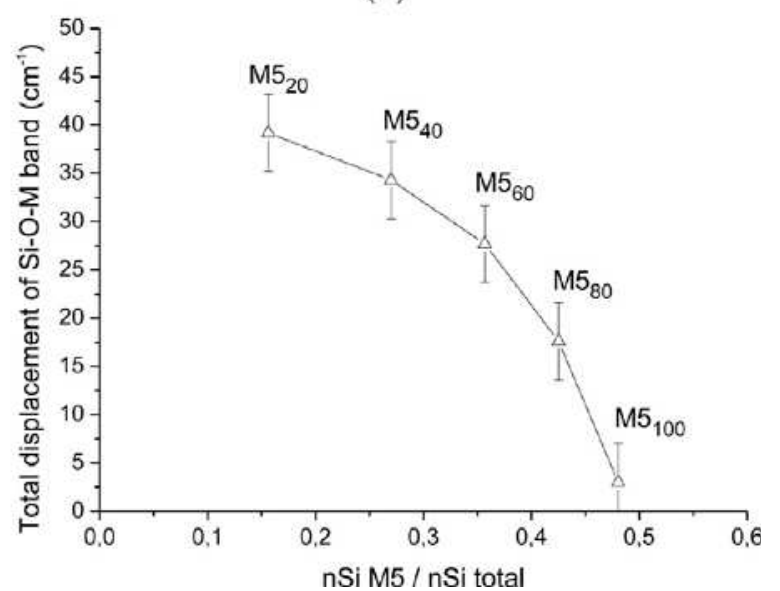

Figure 6. FT $\mathbb{R}$ total displacem ent variation value according to the (nSi introduced) / (nSi total) ratio for (A) SiH00 , (B) $\mathrm{FD} \mathrm{S}_{\mathrm{X}} \mathrm{SiH}_{\mathrm{H}} 0 \mathrm{O}_{100 \mathrm{x}},(\mathrm{C}$ ) Sit00 ${ }_{X} M 5_{100 x}$, (D) FD S S M 5 $5_{100 X}$, (E) FD $S_{X}$, and (F) M 5 $5_{X}$.

conoborated by the sbpe of the aurve near zero for $\mathrm{M} 5_{100}$, characteristic of a saturated siliceous medim and by its increase $w$ th the augm entation of the am ount of FD S silica.

Sit $00_{X} M 5_{100 X}$ Series. Two distinct types of behavibr and an interm ediate behavior are observed. For X < 40, the m ixture appears hom ogeneous, but evolves with tim e. $\mathrm{N}$ ext, there appears a central collapse, suggesting that som e species have precipitated..$^{39}$ For X 40, two phases appear; the bwer portion resem bles a dense geopolym er, while the upper portion exhibits a glassy aspect. M oreover, the volim e of the upper phase increases $w$ ith the increase of Sit 00 silica. Regardless of the sam ple, the m ore the M 5 quantity increases, the greater the shiff of the Si O - M band and the sbpe decreases. As for the FD $S_{X} S_{14} 0 O_{100 x}$ substitution, the bw-reactive silica Si 00 
(crushed quartz) has little in uence on the form ation of the netwolk and the viscosity. This di erence in reactivity is directly rebted to their speci c surface area, 1 and $202 \mathrm{~m}^{2} / \mathrm{g}$ for Sit00 and M 5, respectively.

FD $S_{X}$ series. Two types of consolidation are observed. For X $<60$, there are two separate phases; the bwer portion has a dense geopolym er appearance without cradking, while the upperphase show s a glassy feature $w$ ith a porous interface. For X 60, smples after consolidation show heterogeneities because of the release of $\mathrm{H}_{2}$ gas and the am ount of siliceous species in the reactive m edim. These species are the origin of the form ation of various phases. The variation in the am ount of FDS silica fime certainly causes a di erent distribution of observed phase within the geopolym er foam, ie., silica gel, $\mathrm{K}_{2} \mathrm{SiO}_{2} \mathrm{O}_{5}$ com pound, zeolite, and the geopolym er netwolk. ${ }^{25}$ The value of the shift of the Si- O - M band decreases $w$ ith the augm entation of the am ount of FD S silica fum e. FD $S_{20} / F^{\prime} S_{40}$ and $\mathrm{FD} \mathrm{S}_{60} / \mathrm{FD}_{80}$ show nearty identical nal displacem ent values of approxm ately 32 and $26 \mathrm{~cm}^{-1}$, respectively. These variations are in agreem ent $w$ ith the zones identi ed previously (speci cally for $\mathrm{X}<60$, a higher value of displacem ent, and for $X \quad 60$, a bwer value) and $w$ th the work of Prudhom $m$ e et $\mathrm{al}^{25}$ Indeed, the reduction of FD S silica fum e w illprom ote the form ation of a geopolym er network, and is form ation will be m ore signi cant than the high displacem ent value. For bw levels of silica, the com position approaches a single geopolym er netwolk. In contrast, when the am ount of FD S silica fime increases, there is competition between the formation of di erent com pounds, such as silica gel, $\mathrm{K}_{2} \mathrm{Si}_{2} \mathrm{O}_{5}$ com pound, the zeolite phase, and the geopolym er network.

M $5 \mathrm{x}$ Series. As before, the M $5_{\mathrm{X}}$ series shows two types of behavior. ForX 60 , a single phase is obtained, which has the appearance of a gel that w ill eventually collapse. For $X<60$, two phases appear; the bwer portion resembles a dense geopolym er, while the upper phase exhibits a glassy aspect. As previousty described, the increase in available sitica causes a decrease in displacem ent as a result of the com petition between the di erent allum inosilicate species. W hen the am ount of silica is su cient to form a netwolk geopolym er, it form $\mathrm{s}$ very quidkly $(0<X<40)$. In the opposite case ( $X \quad 40)$, there is again a competition between a geopolym er netwolk and a saturated siliceous species liquid, which leads to a gel. These phenom ena are also observable by the variation in sbpes.

$\mathrm{Si} 400_{\mathrm{x}}$ Series. Finally, for the $\mathrm{Si} 40 \mathrm{O}_{\mathrm{x}}$ series, two phases can be distinguished for all the samples. The bottom phase has features of a dense geopolym er, whereas the upperphase shows a vitreous aspect and presents a great deal of shrinkage, and their interface shows cradking. The augmentation of the amount of SiHOO sitica has no in uence on the Si-O-M band shiff valle, which rem ained approxim ately $40 \mathrm{~cm}^{-1}$ for all sam ples. This highights the very bw reactivity of Sit00 in the reaction m edim. In this case, the Sit00 silica sim ply plays the role of reinforcem ent. ${ }^{42} \mathrm{~N}$ evertheless, the observed dem ixing (geopolym er phase and gel upon the surface) suggests that the consolidated sam ple is com posed of at least two networks, in accordance $w$ ith the work of Autef et al ${ }^{43}$

Sum ary of the Reactivity and the Nature of the Netwolks Form ed. To compare the di erent form ulations, Figure 6 shows the displacem ent value of the Si O - M band determ ined by FT $\mathbb{R}$ spectroscopy as a function of the ratio of the num ber of m oles of silica ( $\mathrm{SH} 00, \mathrm{M} \mathrm{5}$, or FD S) added by the total num ber of silica in the form ulation.
Si400 In luence. The bw shifl of the band from 38 to 46 $\mathrm{cm}^{-1}$ for sam ples $\mathrm{Si4} 0 \mathrm{O}_{20}$ to $\mathrm{Si4} 0 \mathrm{O}_{100}$ (Figure 6A) as a function of the nSit00/nSi total ratio is characteristic of both the form ation of a geopolym er netwolk and the coating of the quartz grain by an alum inosilicate binder.

In the presence of reactive silica, increasing the nSi400/nSi total ratio causes an increase in the displacem ent value from 29

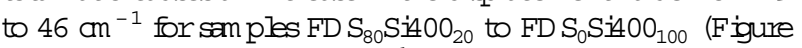
6B) and from 12 to $46 \mathrm{~cm}^{-1}$ for somples $\mathrm{SiH} 00_{20} \mathrm{M} 5_{80}$ to $\mathrm{Si}$ i $0 \mathrm{O}_{100} \mathrm{M} 5_{0}$ (Figure $6 \mathrm{C}$ ). This characterizes the nonreactivity ofSit00 silica $w$ ithin the reaction m edim because there is little or no release of siliceous species. N evertheless, the variations are not identical with those of the FD S or M 5 silicas. The di erences observed re ect their reactivity, which is a function of their ability to release siliceous species in the reaction m edim , thus m odifying the speciation equitibrim s.

FDS and M 5 Silica. This reactivity was con $\mathrm{m}$ ed during the formation of the FD SXM $5_{100 x}$ series. The change of the nSIM 5/nSi total ratio results in a slight change in the displacem ent value from 26 to $19 \mathrm{~cm}^{-1}$ for samples $\mathrm{FD} \mathrm{S}_{80} \mathrm{M} 5_{20}$ to $\mathrm{FD} \mathrm{S}_{20} \mathrm{M} 5_{80}$ (Figure $6 \mathrm{D}$ ). The substitution of FD S by M 5 silica leads to modi cations in the speciation equilibrim $s$, thus prom oting the form ation of a sitica gel to the detrim ent of the other netwolks.

These features are again highighted for the variation series $F D S_{X}$ (Figure $6 \mathrm{E}$ ) and $M 5_{X}$ (Figure $6 F$ ). A slight decrease in the shiff from 32 to $28 \mathrm{~cm}^{-1}$ for FD $S_{20}$ to $F D S_{100}$ and a sharp decrease of the displacem ent from 39 to $6 \mathrm{~cm}^{-1}$ for sam ples M $5_{20}$ to M $5_{100}$ are noted. Consequently, unlike the FD S silica, with the more reactive M 5 silica, the siliceous species are avaibble m ore quidkly to form a gel and therefore decrease the value of displacem ent.

Gbbal Reactivity. To exacerbate the reactivity of the siliceous species, the displacem ent of the Si O - M band as a function of the sbpe for all the sam pleswaspbtted in Figure 7. Three areas can be de ned $w$ th values of the sbpe around -0.18 and $-0.10 \mathrm{~cm}^{-1} \mathrm{~s}^{-1}$. Above $-010 \mathrm{~cm}^{-1} \mathrm{~s}^{-1}$, supersaturated siliceous speciesw ill form a Si-rich alum inosilicate gel, whereas bebw this value, there $w$ in be form ation of di erent

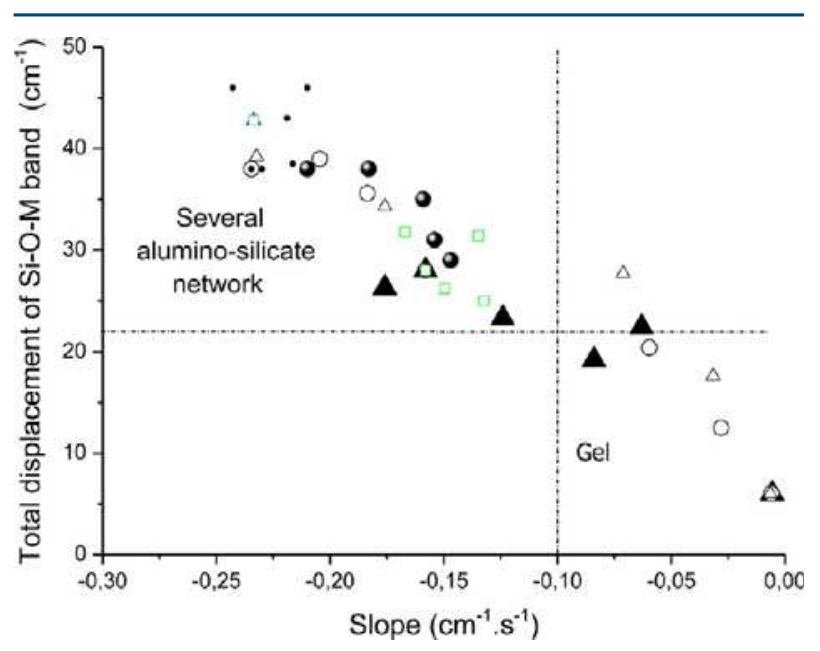

Figure 7. Evolution of the total displacem ent value versus the FT $\mathbb{R}$ displacem ent sbpe value of Si O-M band position for ( Ied triangle) FD S $S_{X} M 5_{100 X}$, (open circle) Si400 M 5 $5_{100 x}$, (large Iled circle) Sif00 $F_{X} S_{100 X}$, (open triangle) M 5 , (green box) FD S , and (sm all Ied circle) $\mathrm{Sin} 0 \mathrm{O}_{\mathrm{X}}$ series. 
(A1)

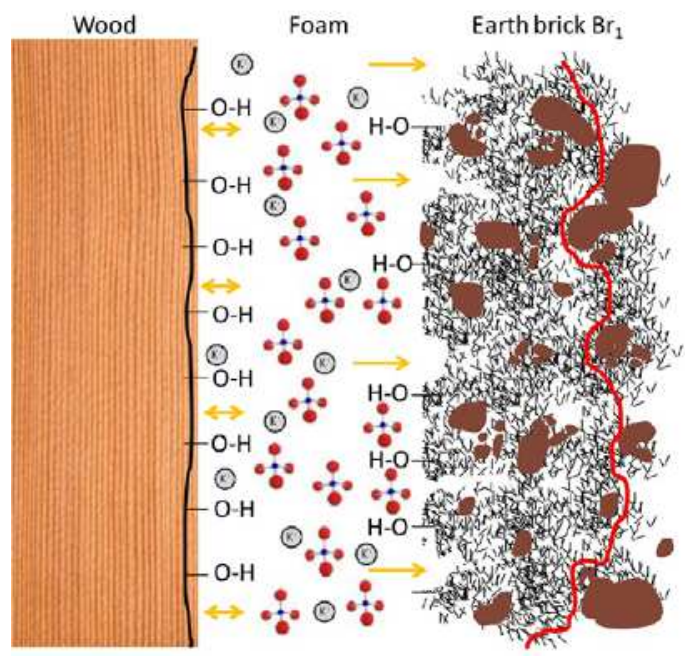

(A2)
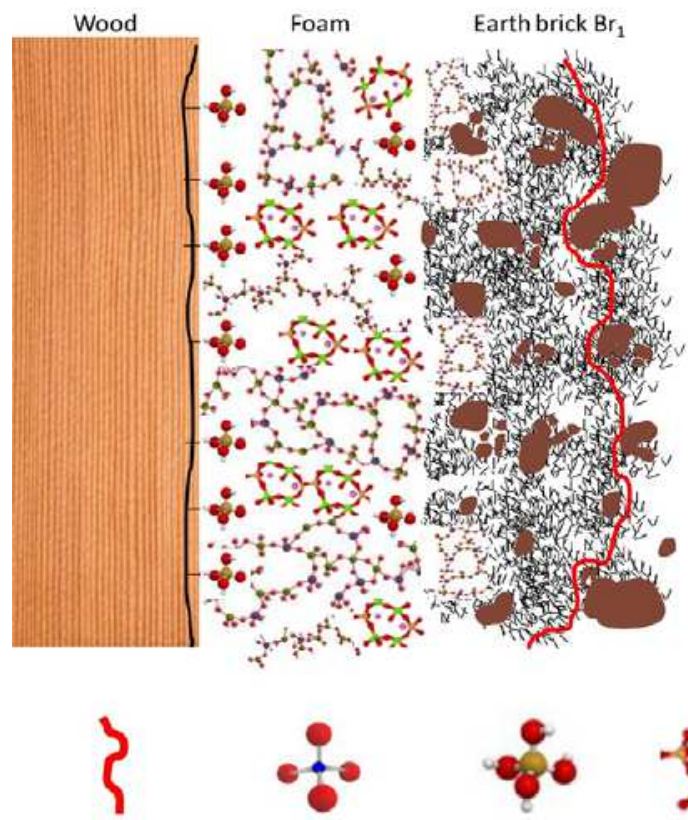

$\begin{array}{cccc}\text { Penetration } & \text { Aluminate } & \text { Silicic } & \text { Silica } \\ \text { limit } & \text { and silicate } & \text { acid } & \text { gel }\end{array}$

(B1)

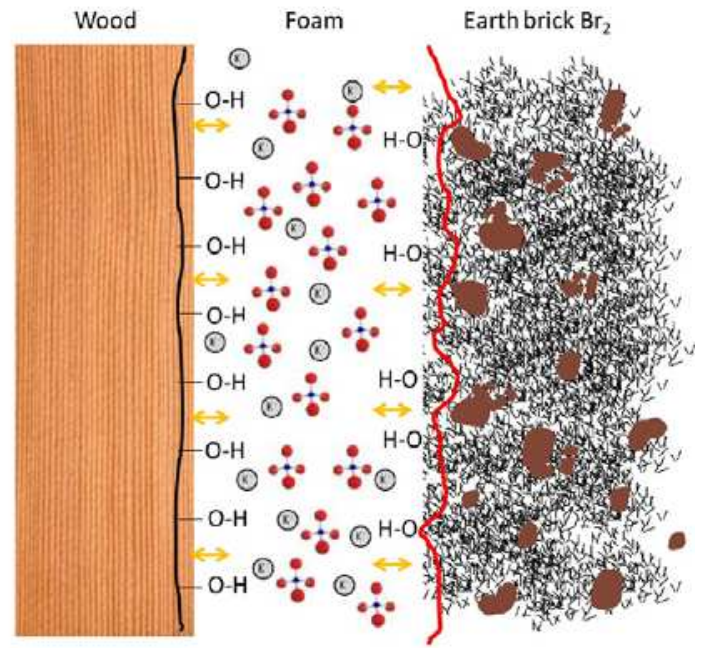

(B2)

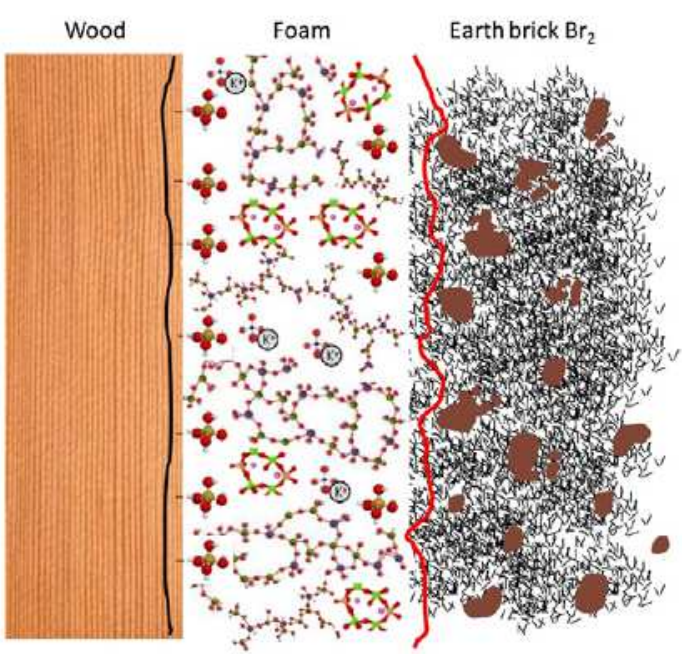

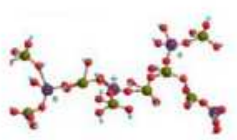

Aluminosilicate network

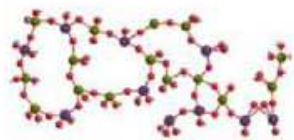

\section{Geopolymer} network

Figure 8. Form ation schem e of FD $S_{100}$ (fom) in interaction w ith wood and bridk $B r_{1}(A)$ and $B r_{2}(B)$ at the beginning (A1, B1) and at the end of the reaction (A2, B2).

alum inosilicate netwolks. This comesponds to a value of displacem ent ranging between 0 and $22 \mathrm{~cm}^{-1}$. This observation is comoborated by the wolk of $\mathrm{G}$ ao et al., which shows that for a value of displacem ent ranging between 0 and $22 \mathrm{~cm}^{-1}$, there is preferential bridging between the siliceous species, whereas for values higher than $22 \mathrm{~cm}^{-1}$, there is form ation of various netwolks. M oreover, the position of synthesized compounds on the temary $\mathrm{Si}-\mathrm{Al}-\mathrm{K}-\mathrm{O}$ (Figure 2) shows that the di erent considered form ulations are bcated in the areas of $m$ aterials leading to gels or sedim ented materials presenting severalphases. This is in perfect agreem ent $w$ ith the results obtained.M oreover, itcan de ne porousm aterials as the sam ples presenting a value of sbpe ranging between - 018 and $-010 \mathrm{~cm}^{-1} \mathrm{~s}^{-1}$.

From these data, it is thuspossible to delm it the existence of various types ofm aterials according to the displacem ent of the Si O - M band and the sbpe of the arrve. For a given silicate solution, three areas have been identi ed: an area comesponding to a Si-rich alum inositicate gel, an area composed of di erent porous netw olks, and an area com posed of di erent dense netw orks. M oreover, all previous analyses, perform ed at 
constant water content, suggest that it would be possible to m ove from one area to another by changing the water am ount.

\section{ISCUSSION}

The previous study heiped highlight the di erentenvironm ents present in the binder after contact $w$ ith the structuralm aterials (earth bridk and wood) , as well as an existence range of several types of $m$ aterials by FT $\mathbb{R}$ spectroscopic analysis. In fact, the existence of di erent networks, especially during the FD S $S_{X} M 5_{100 x}$ substitution series, has been shown. From all of these data, the binder form ation schem e is proposed for the two types of assem bly in Figure 8. Figure 8 puts forth the various hypotheses on the interaction between materials explained bebw. For the two types of assem blies, the wood and the bridk are represented. The evolution of species $w$ thin the binder is given for di erent tim es during the consolidation. It should be noted that there is a scale factor between the representation of wood, bridk, and species. For each tim e, the di erent contributions and the di erent networks described above were reported.

Interaction of W ood/Binder.M onphobgical (wettability) and stuctural (NMR and FTR ) anakyses have shown the absorption of the binder by wood porosity. M oreover, it has been shown that after consolidation, the Si-ridh alum inosilicate network and silica gelwere stillpresent. The geopolym erphase is also present but in smaller quantities. The decrease in geopolym er phase suggests that there has been a decrease in siliceous species able to react $w$ ith the allm inous species. This defect of concentration in siliceous species $m$ ay be characteristic of an exchange $w$ th the wood.

Consequently, at the time of the contact with wood, as shown in Figure 8 (A1 and B1), the exchange highlighted in previous work ${ }^{12}$ is thus ensured by the potassium silicate solution. This gives the bcal form ation of silicic acid (band at - 113 ppm ). This type of acid can be form ed w th a reduction ofpH value, whidh can ocaurduring the transfer of the m ixture within the wood bers, wood being acidic in nature. This phenom enon will result in the creation of siliceous depolym erized species richer in allm inum (band at - 80 ppm ). These data comoborate the observations by FTIR spectroscopy, initiated by an exchange of siliceous species in supersaturation (form ation of silicic acid justi ed by the increase of the Si O M band position) , fllowed by the depolym erized species (light shiff of the band position).$^{43}$

Interaction of $\mathrm{Br}_{2} / \mathrm{Binder}$. In the some manner, the morphobgical and stuctural analyses showed a sbow and di use absonption of the binder by the $\mathrm{Br}_{2}$, which is characterized by a sm all pore size. The some contributions, ie., a geopolym er network, a Sirrich alum inosilicate environ$\mathrm{m}$ ent, and silica gel, are noted. The siliceous species in solution, in the presence of the surface of bridk, will interact and form sim ultaneously (i) the silicic acid from the penetration of the binder and (ii) a geopolym er phase because of the bcal attadk of the clay particles. The form ation of depolym erized species also suggests that an excess of siliceous species (in very sm all am ount) does not participate in the network form ation (bw intensity at - 80 ppm ) . In addition, FT $\mathbb{R}$ spectroscopy re ects the solvent absorption $\mathrm{w}$ ith the creation of silicic acid as before, as shown in Figure 8B1. Then, there is the formation of di erentnetw orks justi ed by the large displacem ent of the $\mathrm{Si}$ $\mathrm{O}-\mathrm{M}$ band, as show in Figure 8B2.
The presence of these depolym erized species and of silicic acid can certainly prom ote interactions and enhance adhesion between m aterials.

Interaction of $\mathrm{Br}_{1} / \mathrm{B}$ inder. In this case, the m orphological (visual and wettability tests) and structural (NM R and FTR $\mathbb{R}$ ) analyses showed very strong absorption of the binder by the bridk $B r_{1}$ because of its brge pore sizes. The m ajor identi ed networks are the geopolymer, the Si-rich allum inosilicate compound, and the silica gel $w$ ith the largest contribution. Again, upon contact $w$ ith the bridk surface, there is form ation of silicic acid, followed by a quidk di usion through the m aterial. This creates bcally, in sm all am ounts, the geopolym ernetworks and thus increases the form ation of sitica gel The absence of the band at - 80 ppm (depolym erized species) can be explained by the reactions in the bridk that consum e all available species. FT $\mathbb{R}$ analysis con $\mathrm{Im}$ s the various interactions leading to the di erent netwolks.

\section{CONCLUSDN}

This study was focused both to describe and to understand the phenom ena that ocaur between a geopolym er binder and structural m aterials, such as m ud bridk and wood, and also to identify the e ect of silideous species on the binder consolidation.

Various form ulations containing di erent silicas were used to establith the areas of com positions, which result in either a hom ogeneous m aterial or di erent types of netw olks, depending on the reactivity of silica introduced. All of these results, associated with N M R ( ${ }^{29} \mathrm{Si}$ ) and FT $\mathbb{R}$ analysses, allowed for the com plete understanding of transfers that occur at the interfaces. The di erent netw ork contributions highlighted in the porous geopolym er binder (FD $S_{100}$ ) were modi ed during the consolidation and depend on the interactions $w$ ith the bridk and the wood. In partiarlar, di erent proportions of the geopolym erphase were observed as a result of the contact $w$ ith the bridks and the form ation of silicic acid in the majority resulting from the contact $w$ ith wood.M oreover, these data are closely related to the am ount and nature of siliceous species available in solution that govern the nature of the m onom ers and the form ation kinetics.

Additionally, to complem ent previous studies and validate the feasibility of such building system, a full scale $\left(2 \times 2 \mathrm{~m}^{2}\right)$ wall was built, and various tests in a clin ate cham ber were perform ed to investigate the hygrotherm al regulation e ciency.

\section{ASSOCDATED CONTENT}

* Supporting Inform ation

Tables S1-S4, as noted in the text. This $\mathrm{m}$ aterial is available free of charge via the Intemet at http://pubsacsorg.

\section{AUTHOR $\mathbb{N} F O R M A T D N$}

Corresponding Author

*E-m ail: sylvierossignol@ unilim fr. Tel: +33 587502564 .

Notes

The authors declare no com peting nancial interest.

\section{ACKNOW LED GM ENTS}

W e thank Isabelle Sobrado and Jesus Sanz from Instihuto de Ciencia de M ateriales de M adrid, Consej Superior de Investigaciones C ienti cas (C SIC) , M adrid, Spain. 


\section{REFERENCES}

(1) M cLellan, B .C .;W illiam S, R .P .; Lay, J .; Van Riessen, A .; Corder, G. D. Costs and carbon em issions for geopolymer pastes in com parison to ordinary portland cem ent. J. Clemer Prod. 2011, 19, $1080-1090$

(2) Venkataram a Reddy, B. V ; Jagadish, K . S. Em bodied energy of com $\mathrm{m}$ on and altemative building $\mathrm{m}$ ateríls and technobgies. Energy Build. 2003, 35, 129- 137.

(3) D uxson, P .; Provis, J.L .; Lukey, G .C .; Van D eventer, J.S.J.The role of inorganic polym er technology in the developm ent of green concrete'. Cem . Concr. Res. 2007, 37, 1590- 1597.

(4) M inke, G . Building with Earth, 2nd ed; Bitkhauser: Basel, 2006.

(5) H ouben, $\mathrm{H}$.; G uillaud, $\mathrm{H}$. Trate de Construction en Tere, 3rod ed, Parentheses: M arseille, 2006.

(6) Fontaine, L .; Anger, R . Batir en Tene, 1sted.; Belin: Paris, 2010.

(7) M orton, T .Earth M asonry: Design and Construction Guidelines, 1st ed.; BRE Press: Bracnell, 2008.

(8) M orel, J.; M esbah, A .; O ggero, M .; W alker, P. Building houses $w$ ith bcal $m$ aterials: $M$ eans to drastically reduce the environm ental in pact of construction. Build. Environ. 2001, 36, 1119- 1126.

(9) Alinson, D ; H all, M . H ygrotherm al anakysis of a stabilised ram m ed earth test building in the UK . Energy Build. 2010, 42, 845852.

(10) Law rence, M .; H eath, A .C .; W alker, P.D evelppm ent of a N ovel Binder for M ortar for Un red Clay Bridks. Proceeding of Second International Conference on Sustainable Construction Materials and Technologies; Ancona, Itaky, tune 28- 30, 2010.

(11) PrudH om m e, E.; M idhaud, P.; Joussein, E .; Peyratout, C .; Sm ith, A ; Sauvat, N . et al Geom aterial foam to reinforce wood. Proceeding of the 34th Intemational Conference on Advanced Ceram ics and Com posites; D aytona Beach, FL, Jenuary 24- 29, 2010.

(12) G ouny, F .; Fouchal, F .; M aillard, P .; Rossignol, S.A geopolym er mortar for wood and earth structure. Constr. Build. M ater. 2012, 36, 188- 195.

(13) Gouny, F .; Fouchal, F .; Pop, O .; M ailard, P .; Rossignol, S. $M$ echanical behavior of an assem bly of wood-geopolym er- earth bridks. Constr. Build. M ater. 2013, 38, 110- 118.

(14) D avidovits, J. Chem istry and Applications; Instihut G eopolym ere: Saint $Q$ uentin, 2008

(15) $\mathrm{Xu}, \mathrm{H}$. G eopolym erisation of alum inosilicate m inerals. PhD . Thesis, University of M elboume, 2001.

(16) Autef, A .; bussein, E .; Poulesquen, A .; G asgnier, G .; Pronier, S .; Sobrados, I.; Sanz, J.; Rossignol, S. Influence ofm etakaolin purities on potassim geopolym er form ulation: The existence of severalnetw orks. J. Colbid Interface Sci. 2013, 408, 43-53.

(17) PrudH om M e, E.; M ichaud, P .; Jussein, E .; C hacens, J. M .; Rossignol, S.Role of alkaline cations and water content on geom aterial foam s: M onitoring during form ation. J. N on-Cryst. Solids 2011, 357, $1270-1278$

(18) Lee, W . K. W ; Van Deventer, J. S. J. Use of infrared spectroscopy to study geopolym erization of heterogeneous am orphous allm inosilicates. Langnuir 2003, 19, 8726- 8734.

(19) G ao, X .X .; Autef, A .; Prudhom m e, E .; M ichaud, P .; bussein, $\mathrm{E} . ;$ Rossignol, $\mathrm{S}$. Synthesis of consolidated $\mathrm{m}$ aterials from alkaline solutions and m etakaolin: Existence of dom ains in the Al Si-K/O temary diagram . J. SolG el Sci. Technol 2012, 65, 220- 229.

(20) Benoit, Y. Le Guide des Esences de Bois, 2nd ed.; Eyrolle: Paris, 2008.

(21) Engelhardt, G .; Zeigan, D .; Jandke, H .; H oebbel, D .; W ìker, W . ${ }^{29} \mathrm{SiN} \mathrm{M} \mathrm{R} \mathrm{spectroscopy} \mathrm{of} \mathrm{silicate} \mathrm{solutions.} \mathrm{II.} \mathrm{O} \mathrm{n}$ the dependence of structure of silicate anions in water solutions from the $\mathrm{N}$ a/Siratio. $\mathrm{Z}$. Anorg. Alg. Chen . 1975, 418, 17- 28.

(22) Engelhardt, G .; Lohse, U .; Sam Oson, A .; M agi, M .; Tarm ak, M .; Lippm aa, E.H igh resolution ${ }^{29}$ SiN M R ofdealum inated and ultrastable Y-zeolites. Zeolites $1982,2,59-62$.

(23) Rossignol, S.; PrudH om me, E.; M idhaud, P ; Jussein, E.; Sobrado, I.; Sanz, J. Reply to the J. Provis and SA . Bemal com m ent about the article "Structural characterization of geom aterial foam $\mathrm{s}$. Therm al behavior". J.N on-Cryst. Solids. 2012, 358, 717- 718.
(24) Autef, A. Form ulation geopolym ere: In uence des rapports m obires Si/K etSi/A lsur les reactions de polycondensation au sein de gels alum inosilicates. PhD . Thesis, U niversity of Lim oges, 2013.

(25) Prud H om m e, E. Role du cation alcalin et des renforts m ineraux et vegetaux sur les m ecanism es de form ation de geopolym eres poreux ou denses. PhD . Thesis, University of Lim oges, 2011.

(26) Tognonvi, M . T.; M assiot, D .; Lecom te, A ; Rossignol, S.; Bonnet, J.P . Identification of solvated species present in concentrated and dilute sodium silicate solutions by com bined ${ }^{29} \mathrm{SiNM} R$ and SAXS studies. J. Colbid Interface Sci. 2010, 352, 309- 315.

(27) Chem tob, S.M .;Rossm an, G .R .; Stebbins, J.F .N aturalhydrous am orphous silica: $Q$ uantitation of netwolk speciation and hydroxyl contentby ${ }^{29} \mathrm{SiM}$ AS N M R and vibrational spectroscopy.Am .M ineral $2012,97,203-211$.

(28) Spinde, K .; Pachis, K .; Antonakaki, I.; Paasch, S.; Brunner, E .; $\mathrm{D}$ em adis, K . D . Influence of polyam ines and related m acrom oleaules on silicic acid polycondensation: Relevance to "soluble silicon pools"? Chen .M ater. 2011, 23, 4676- 4687.

(29) Duxson, P.; Provis, J. L .; Lukey, G . C .; Separovic, F .; Van Deventer, J. S. J. ${ }^{29}$ Si NMR study of structural ordering in alm inosilicate geopolym er gels. Langn uir 2005, 21, 3028- 3036.

(30) Z ibouche, F .; Kerdjoudj, H .; dEspinose de Lacaillerie, J.B .; Van D am m e, H . G eopolym ers from A gerian metakaolin. Influence of secondary m inerals. Appl C lay Sci. 2009, 43, 453- 458.

(31) Thom pson, J. G . ${ }^{29} \mathrm{Si}$ and ${ }^{27} \mathrm{Al}$ nuclear m agnetic resonance spectroscopy of $2: 1$ clay m inerals. C lay M iner. 1984, 19, 229- 236.

(32) Dove, M . T. The use of ${ }^{29}$ Si M ASNM R and M onte Carto m ethods in the study ofA $1 /$ Siordering in silicates. Geodem a 1997,80, 353- 368 .

(33) Sen, S.; Youngm an, R. E. NM R study of $Q$ speciation and connectivity in $\mathrm{K}_{2} \mathrm{O}$ - Si ${ }_{2}$ glasses w ith high silica content.J.N on-Cryst. Solids 2003, 331, 100- 107 .

(34) $M$ eneau, $F$.; $N$ eville G reaves, $G$.; $W$ inter, $R$.; Vaills, $Y$.; $W$ AXS, $\mathrm{N}$.M .R. studies of interm ediate and short range order in $\mathrm{K}_{2} \mathrm{O}-\mathrm{Si}_{2}$ glasses. J.N on-Cryst. Solids 2001, 293, 693-699.

(35) De Jong, B .; Super, H . T. J.; Spek, A. L.; Velom an, N .; N achtegaal, G .; Fischer, J.C .M ixed akalisystem S: Structure and ${ }^{29} \mathrm{Si}$ M A.SN M R ofL i $\mathrm{SiO}_{5}$ and $\mathrm{K}_{2} \mathrm{SiO}_{2}$. Adta Crystallogr.Sect. B: Struct.Sci. $1998,54,568-577$.

(36) Todea, M .; Turau, R.V.F .; Frentil, B .; Tam asan, M .; M ocuta, H .; Ponta, O ;i Sim on, S. Am orphous and nanostructured silica and alum inosilicate spray-dried m icrospheres. J. M ol Struct. 2011, 1000, $62-68$.

(37) Pereyra, A .M ;; G iudice, C .A. Flam e-retardant im pregnants for woods based on alkaline silicates. Fire Saf. J. 2009, 44, 497- 503.

(38) Bauer, A .; Berger, G. Kaolinite and sn ectite dissolution rate in high m Obr KO H solutions at 35 and $80{ }^{\circ} \mathrm{C}$.Appl G eochen . 1998, 13, 905- 916.

(39) Tognonvi, M .T .; Rossignol, S .; Bonnet, J.P. Physical-chem istry of sodim silicate gelation in an alkaline medim. J. SolGel Sci. Technol 2011, 58, 625- 635.

(40) Singh, P. S.; Bastow, T .; Trgg, M . Structural studies of geopolym ers by ${ }^{29} \mathrm{Si}$ and ${ }^{27} \mathrm{Al} \mathrm{M}$ ASAN M R . J. M ater. Sci. 2005, 40, 3951- 3961.

(41) Prudhomm E, E.; M ichaud, P.; Jussein, E.; Peyratout, C ; Sm ith, A .; A mii-C bacens, S.; C bcens, J.M .; Rossignol, S. Silica fum e as porogent agent in geo $m$ aterials at bw tem perature. J.Eur.Ceram .Soc. $2010,30,1641-1648$.

(42) Autef, A .; Jussein, E .; G asgnier, G .; Rossignol, S. Role of the silica source on the geopolym erization rate. J.N on-Cryst. Solids. 2012, $358,2886-2893$.

(43) Autef, A .; Prud'H om m e, E .; bussen, E .; G asgnier, G .; Pronier, $\mathrm{S}$.; Rossignol, $\mathrm{S}$. Evidence of a gel in geopolym er com pounds from pure m etakaolin. J. SolG el Sci Technol. 2013, 67, 534- 544.

(44) Rowell, R. M . Handbook of W ood Chem istry and W ood Composite, 2nd ed; CRC Press: Boca Raton, FL, 2012. 